\title{
New Records of Microcystins in Some Bulgarian Water Bodies of Health and Conservational Importance
}

\author{
Vera Pavlova1 ${ }^{*}$, Maya Stoyneva², Vesela Georgieva1, Desislav Donchev³, Lisa Spoof ${ }^{4}$, \\ Jussi Meriluoto ${ }^{4}$, Zlatka Bratanova ${ }^{1}$, Irina Karadjova ${ }^{5}$ \\ ${ }^{1}$ National Centre of Public Health and Analyses, Sofia, Bulgaria \\ 2Department Botany, Faculty of Biology, Sofia University “St. Kliment Ohridski”, Sofia, Bulgaria \\ ${ }^{3}$ Team Consult Ltd., Sofia, Bulgaria \\ ${ }^{4}$ Department of Biochemistry and Pharmacy, Ábo Akademi University, Turku, Finland \\ ${ }^{5}$ Faculty of Chemistry and Pharmacy, Sofia University "St. Kliment Ohridski", Sofia, Bulgaria \\ Email: ${ }^{*}$ vera pavlova@abv.bg
}

Received 13 March 2014; revised 1 April 2014; accepted 15 April 2014

Copyright (C) 2014 by authors and Scientific Research Publishing Inc.

This work is licensed under the Creative Commons Attribution International License (CC BY).

http://creativecommons.org/licenses/by/4.0/

(c) (i) Open Access

\begin{abstract}
Microcystins cause acute hepatotoxicity and chronic liver tumor promotion. This study presents the results of HPLC DAD analyses and their LC-MS confirmation of samples from five Bulgarian water bodies (reservoirs Stoudena, Pchelina, Bistritsa and lakes Dourankoulak, Vaya). The total concentration of microcystins in water samples ranged from 0.1 to $26.5 \mu \mathrm{g} / \mathrm{l}$. The amount of microcystins in the biomasses ranged from 11.4 to $49.6 \mu \mathrm{g} / \mathrm{g}$ (d.w.). The high percent of positive samples in which the most toxic microcystin-LR is recorded, can serve as a strong alarm for the necessity of a serious study and relevant discussion of the problem with responsible authorities at national level.
\end{abstract}

Keywords

Cyanobacteria, Cyanotoxins, Microcystins

\section{Introduction}

Cyanoprokaryotic/cyanobacterial blooms in surface waters resulting generally from anthropogenic pollution with nitrogen and phosphorous are a well-known worldwide problem. Adverse health effects for humans and

${ }^{*}$ Corresponding author.

How to cite this paper: Pavlova, V., Stoyneva, M., Georgieva, V., Donchev, D., Spoof, L., Meriluoto, J., Bratanova, Z. and Karadjova, I. (2014) New Records of Microcystins in Some Bulgarian Water Bodies of Health and Conservational Importance. Journal of Water Resource and Protection, 6, 446-453. http://dx.doi.org/10.4236/jwarp.2014.65044 
animals are associated with cyanobacterial toxins such as microcystins and nodularin [1]. Microcystins (MC) cause acute hepatotoxicity and chronic liver tumor promotion. World Health Organization (WHO) has recommended a provisional guideline value for MC-LR $1 \mu \mathrm{g} / \mathrm{l}$ for drinking water [2]. Until now MC have been isolated from several species of freshwater genera Microcystis, Anabaena, Oscillatoria, etc. [3]. In spite of the recognition of the problem of blooms and related potential presence of microcystins in Bulgarian waters [4]-[7], relevant studies on the topic are extremely scarce, as summarized in recent general papers on the biodiversity of Bulgarian wetlands [8]-[10]. The deepening of the problem itself and its higher admission are proved by the interesting fact that the first series of MC-investigations in Bulgaria, which started in 2004 and were carried out by our research group [8] [11] [12], were more recently followed by studies of another group [13]-[15]. However, yet all the surveys on the presence of MC in Bulgaria are concerning only particular water bodies and based generally on singular samplings. Therefore the aim of the present paper is to promote additional knowledge on the topic, which concerns not only the health of the population, but also the so-called ecosystem health, and additionally to outline the first incontestable checking for the nodularin in Bulgaria (despite its negative result).

\section{Material and Methods}

\subsection{Studied Sites}

In the summer months of 2011 sampling was carried out in five Bulgarianwater bodies of health and conservational importance (Figure 1). The first three inland reservoirs are located in the Western part of the country, on the European Bird migration route Via Aristotelis. The Black Sea coastal lakes Dourankoulak and Vaya, located on the Bird migration route Via Pontica, shelter many rare and endangered bird species and are well-known sites of global, European and national conservational importance. They have been declared as Protected localities, Ramsar sites, Important bird areas and Natura 2000 sites. The five studied water bodies are included with the following identification numbers: Stoudena-IBW1060, Pchelina-IBW 1039, Bistritsa-IBW 1067, Dourankoulak-IBW8825, Vaya-IBW0191 in the Bulgarian Wetlands Inventory [16], where more details on them can be seen.

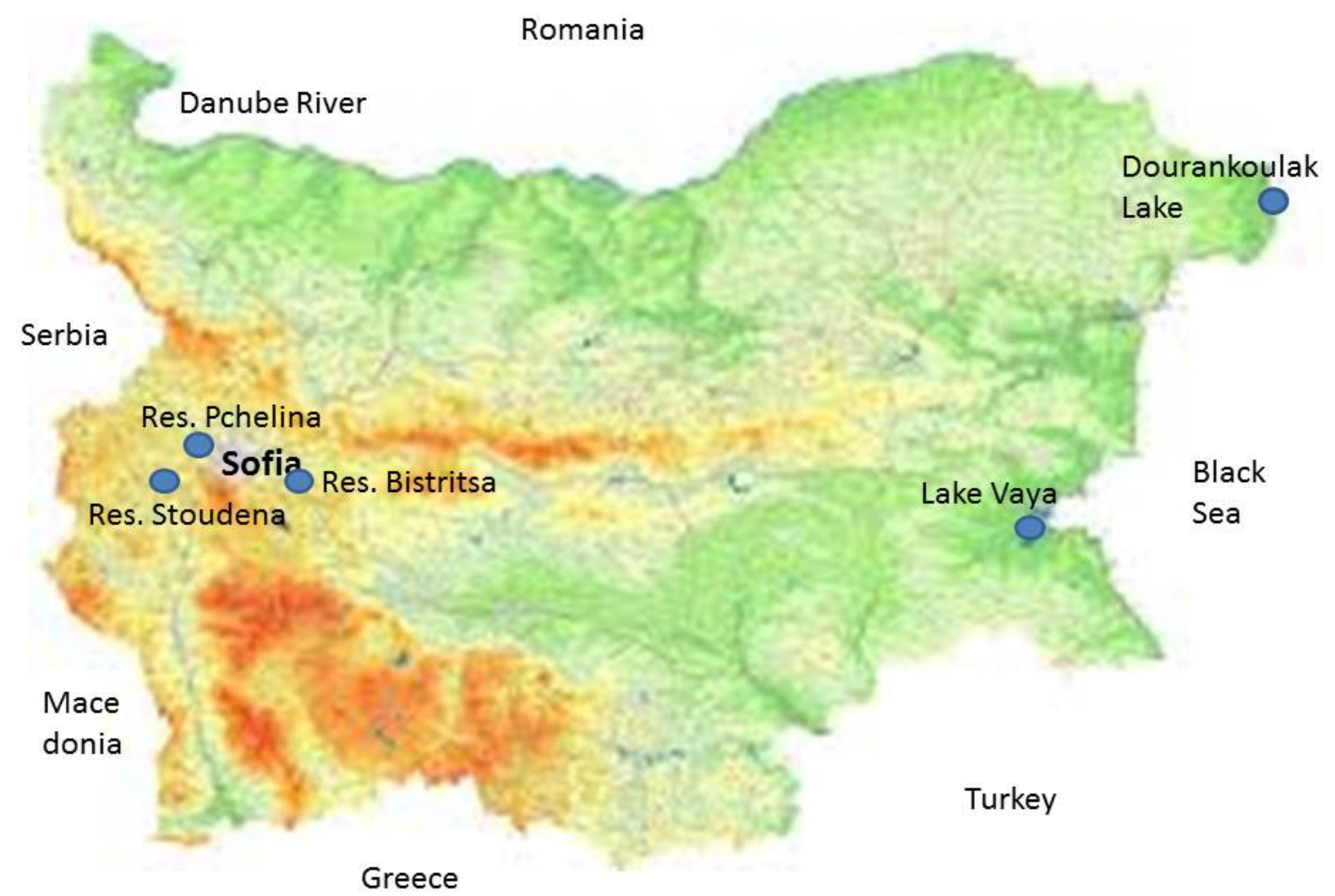

Figure 1. Map of Bulgaria and location of investigated water bodies: Reservoir, Stoudena, ReservoirPchelina, Reservoir Bistritsa, Lake Dourankoulak, and Lake Vaya. 


\subsection{Sampling}

Three liters of water from surface zone were collected in plastic bottles and stored frozen prior to sample preparation. In parallel, biomass samples were collected from water bodies and scum was taken in the littoral shallows with plankton net $(20 \mu \mathrm{m})$. The biomasses were stored frozen and portions of them were defrosted and dried at room temperature prior to the analysis of toxins.

Water samples for biological analyses were collected in 1 liter glass bottles at the same points as the samples for toxins and immediately fixed with $2 \%-4 \%$ formaldehyde. In the laboratory samples were concentrated by sedimentation.

\subsection{Species Composition and Biomass Quantification}

The qualitative analysis was based on taxa determination according to the current taxonomic literature [17]-[21]. Counts were done in a Thoma blood-counting chamber in 8 reiterations with cell as a counting unit. Biomass was calculated after measurement of each cell, using standard stereometrical approximations [22] [23].

\subsection{Analysis of Toxins}

Stored water samples were frozen and defrosted three times to provide cell lysis. After that samples were filtered through nylon membrane filter $0.45 \mu \mathrm{m}$ (Alltech). Extraction of microcystins and nodularin from water samples (1.5 to 2.1) was performed by solid-phase extraction with Empore Extraction Disks C-18 (Varian). Toxins were eluted with methanol. Eluates were dried by gentle stream of nitrogen, re-dissolved in $500 \mu \mathrm{l}$ of $50 \%$ methanol $(\mathrm{v} / \mathrm{v})$, filtered through $0.22 \mu \mathrm{m}$ PTFE syringe filters (ALBET LabScience) and analyzed by HPLC.

Extraction of toxins from dried biomass was performed by ultrasonification of 40 to $60 \mathrm{mg}$ biomass in $1 \mathrm{ml}$ of $50 \%$ methanol $(\mathrm{v} / \mathrm{v})$. After centrifugation the methanolic extracts were filtered through $0.22 \mu \mathrm{m}$ PTFE syringe filters and analyzed by HPLC.

Analyses were performed by HPLC-DAD and HPLC-MS systems.

The HPLC-DAD system for quantitative and qualitative analyses includes Agilent 1200 Series coupled with Diode Array Detector (Agilent Technologies). Toxins were analyzed on a Supelcosil ABZ + Plus column (150 $\mathrm{mm} \times 4.6 \mathrm{~mm}, 5 \mu \mathrm{m}$, Supelco). The binary gradient of mobile phase consisted of milli-Q water $+0.1 \%$ TFA (A) and acetonitrile $+0.1 \%$ TFA (B) (linear increase from $20 \%$ B at 0 min to $46 \%$ B at 25 min and stop time 30 $\min$ ), the flow rate was $1 \mathrm{ml} / \mathrm{min}$, the temperature $25^{\circ} \mathrm{C}$. Chromatograms at $238 \mathrm{~nm}$ were recorded and toxins were identified by the retention time and characteristic UV absorption spectra from 200 to $300 \mathrm{~nm}$.

The HPLC-MS system including Agilent 1200 Series coupled with HCT ultra ion trap detector (Bruker) was used for confirmation of DAD results. Toxins were analyzed on a Supelco Analytical Ascentis C18 column (50 $\mathrm{mm} \times 3 \mathrm{~mm}, 3 \mu \mathrm{m}$, Supelco). The binary gradient of mobile phase consisted of $99 \%$ Chromasolve water, $1 \%$ acetonitrile $+0.1 \%$ formic acid (A) and acetonitrile $+0.1 \%$ formic acid (B) (linear increase from $25 \% \mathrm{~B}$ at 0 min to $70 \% \mathrm{~B}$ at $5 \mathrm{~min}, 70 \% \mathrm{~B}$ to $6 \mathrm{~min}, 25 \% \mathrm{~B}$ at $6.1 \mathrm{~min}$ and stop time $10 \mathrm{~min}$ ), the flow rate was $0.5 \mathrm{ml} / \mathrm{min}$, the temperature $40^{\circ} \mathrm{C}$. Toxins were identified by Auto MS/MS mode.

Purified microcysin $-\mathrm{LR},-\mathrm{RR},-\mathrm{YR},-\mathrm{LA}$ and nodularin (stock concentration of $10 \mu \mathrm{g} / \mathrm{ml}$, Abraxis) were used as external standards.

\section{Results and Discussion}

During the study, presence of microcystins was proved for three of the five investigated water bodies. Their concentrations are represented in Table 1.

The concentration of intra + extracellular microcystins in water samples ranged from 0.1 to $26.5 \mu \mathrm{g} / \mathrm{l}$. The amount of total microcystins in the biomasses ranged from 11.4 to $49.6 \mu \mathrm{g} / \mathrm{g}$ (d.w.). Three of the studied microcystins $(-\mathrm{RR},-\mathrm{YR},-\mathrm{LR})$ were found in Lake Dourankoulak in the reservoir Pchelina only microcystin-RR was detected and in the reservoir Stoudena only microcystin-LR was identified. The results obtained from HPLC DAD did not indicate presence of microcystin-LA and nodularin.

The LC-MS method shows $\mathrm{m} / \mathrm{z} 995.7$ at the retention time of microcystin-LR and $\mathrm{m} / \mathrm{z} 1045.7$ at the retention time of microcystin-YR. According to Poon et al. $[24]$ these $\mathrm{m} / \mathrm{z}$ values are due to the $[\mathrm{M}+\mathrm{H}]^{+}$protonated molecular ions of microcystin -LR and microcystin-YR respectively. At the retention time of microcystin-RR m/z 519.9 was found. Poon et al. describe this value with occurrence of $[\mathrm{M}+2 \mathrm{H}]^{2+}$ double protonated ion as a result 
Table 1. Concentrations and detected by HPLC DAD structural variants of microcystins (intracellular + extracellular) in Bulgarian lakes and reservoirs (d.w.: dry weight, n.d.: not detected).

\begin{tabular}{|c|c|c|c|c|c|}
\hline № & Water source/sample type & Sampling date & Taxa of Cyanoprokaryota found & Biomass (mg/l) & Microcystins \\
\hline \multirow[t]{3}{*}{1} & Stoudena & \multicolumn{4}{|c|}{ Drinking water reservoir for the town Pernik } \\
\hline & water & 03/08/2011 & Unidentified picoplankton & 0.01 & n.d. \\
\hline & water & 28/09/2011 & Raphidiopsismediterranea & $<0.001$ & $-\operatorname{LR} 0.1(\mu \mathrm{g} / \mathrm{l})$ \\
\hline \multirow[t]{8}{*}{2} & Dourankoulak & \multicolumn{4}{|c|}{ Lake for sport, fishing and recreation } \\
\hline & & & Leptolyngbya foveolarum & 0.011 & \\
\hline & & & Merismopedia hyalina & 0.008 & $-R R 127 \mu \mathrm{g} / 1$ \\
\hline & & & Merismopedia tenuissima & 0.002 & $-Y R 5.5 \mu \mathrm{g} / 1$ \\
\hline & water & 29/07/2011 & Microcystis wesenbergii & 6.873 & $-\mathrm{LR} 8.3 \mu \mathrm{g} / 1$ \\
\hline & & & Pseudanabaena mucicola & 0.118 & $(\mathrm{RR}+\mathrm{YR}+\mathrm{LR}) / \mathrm{LR}=26.5 / 8.3$ \\
\hline & & & $\begin{array}{l}\text { Chroococcus sp. } \\
\text { Unidentified colonial coccal cells }\end{array}$ & $\begin{array}{c}<0.001 \\
0.001\end{array}$ & \\
\hline & biomass & $29 / 07 / 2011$ & & & $\begin{array}{c}\text {-RR } 22.1 \mu \mathrm{g} / \mathrm{gd} . \mathrm{w} . \\
\text { - YR-trace } \\
\text { - LR } 27.5 \mu \mathrm{g} / \mathrm{gd} . \mathrm{w} . \\
(\mathrm{RR}+\mathrm{LR}) / \mathrm{LR}=49.6 / 27.5\end{array}$ \\
\hline \multirow[t]{5}{*}{3} & Pchelina & \multicolumn{4}{|c|}{ Reservoir for sport, fishing and recreation } \\
\hline & water & 03/08/2011 & $\begin{array}{l}\text { Aphanizomenonsp. juv. } \\
\text { Unidentified non-heterocystous } \\
\text { filaments }\end{array}$ & $\begin{array}{l}0.097 \\
0.007\end{array}$ & $-\mathrm{RR} 0.5 \mu \mathrm{g} / 1$ \\
\hline & biomass & 03/08/2011 & & & -RR $11.4 \mu \mathrm{g} / \mathrm{gd} . \mathrm{w}$. \\
\hline & water & $28 / 09 / 2011$ & $\begin{array}{l}\text { Aphanizomenonsp. ster. } \\
\text { Planktolyngbyalimnetica }\end{array}$ & $\begin{array}{c}0.772 \\
<0.001\end{array}$ & n.d. \\
\hline & biomass & 28/09/2011 & & & n.d. \\
\hline \multirow[t]{9}{*}{4} & Vaya & \multicolumn{4}{|c|}{ Lake for sport, fishing and recreation } \\
\hline & & & Anabaenopsiselenkinii & 2.919 & \\
\hline & & & Aphanizomenongracile & 8.041 & \\
\hline & & & Cylindrospermopsisraciborskii & 9.294 & \\
\hline & water & 03/08/2011 & Oscillatoriacf. simplicissima & & n.d. \\
\hline & & & Oscillatoriasp. & $<0.001$ & \\
\hline & & & Unidentifiednon- & 53.274 & \\
\hline & & & heterocystousfilaments & 0.318 & \\
\hline & biomass & 03/08/2011 & & & n.d. \\
\hline \multirow[t]{4}{*}{5} & Bistritsa & \multicolumn{4}{|c|}{ Reservoir for sport, fishing and recreation } \\
\hline & water & 03/08/2011 & Microcystiswesenbergii & $<0.001$ & n.d. \\
\hline & water & $28 / 09 / 2011$ & $\begin{array}{l}\text { Anabaena spp. } \\
\text { Aphanothece spp. }\end{array}$ & $\begin{array}{c}0.1 \\
<0.001\end{array}$ & \\
\hline & biomass & $28 / 09 / 2011$ & & & n.d. \\
\hline
\end{tabular}

of the CID in-source area fragmentation of microcystin - RR molecular ion at m/z 1038.6 in capillary exit area. The DAD results are qualitatively confirmed as follows: presence of microcystin $-\mathrm{RR}$ in water and biomass samples of Lake Dourankoulak and reservoir Pchelina, presence of microcystin - LR in water and biomass samples in Lake Dourankoulak and in a water sample in the drinking water reservoir Stoudena, and presence of microcystin -YR in water and biomass samples of Lake Dourankoulak.

Results for the mountain drinking water reservoir Stoudena showed lack of toxins at first sampling but at the 
second date, $0.1 \mu \mathrm{g} / \mathrm{l}$ microcystin-LR was found (Table 1 ). In the microscopically studied samples from the same date only Raphidiopsis mediterranea was found in small amounts (Table 1). This genus, recently supposed to have close phylogenetic relationship and even congenetic origin with Cylindrospermopsis [25], is known either for neurotoxin, or for the hepatotoxin production [3] [26]-[29]. The material studied is not enough to make grounded conclusions for the eventual production of microcystins by this genus, since it could be supposed that the microcystins found in Stoudena had been produced by cyanoprokaryote species belonging to other genera, which already had disappeared from the phytoplankton community, or remained there in neglible, insufficient quantities.

The concentration of the toxin is 10 times lower than WHO limit of $1 \mu \mathrm{g} / \mathrm{l}$. However, the fact that one of the most toxic cyanotoxins has been detected in a drinking water reservoir, can serve as "alarm" and clearly shows that this water body has to be studied and monitored in the future. In 2004 and 2005 microcystins were not found there [8] [11], but it could be supposed that the high air and water temperatures combined with the extremely dry weather with unusual lack of rain between May and September 2011 lead to development of cyanoprokaryotes, which before were not typical for this water body [16]. The other possible reason for the development of this algal group could be searched in the worsening of the sanitary protection of the water basin (contamination with nitrogen and phosphorous, data about which at present are unavailable), or in the combination of both reasons. Therefore, taking into account the harmful effects of this toxin on human and animal health, we strongly suggest that water quality should be controlled and in the nearest future appropriate steps for its improvement should be taken.

During this study the highest microcystin concentration was found in Dourankoulak Lake, where strong algal bloom was observed and proved by classical light microscopic counts (Table 1). These concentrations are lower when comparison with our previous results is made: four times lower than the concentration in 2004 (biomass) and eight times lower than the concentration detected in 2005 [8] [11] Table 1. The algological studies show permanent presence of potentially toxic cyanobacteria in this coastal wetland during the last 20 years [5] [7] [30] and HPLC analysis gives data for microcystins -LR and - RR in 2004, 2005, 2011 and also - YR in 2005 and 2011. Nevertheless that in this survey the concentration of microcystin -LR in the water sample is lower than maximum permissible level $20 \mu \mathrm{g} / \mathrm{l}$ for bathing water [31], this lake should be object of special monitoring. It has susceptibility to eutrophication because of drastic change in its hydrological regime and agricultural activities in the adjacent areas [5] [6] [9] [16].

Positive results were obtained also in the reservoir Pchelina where only microcystin -RR in water and biomass from first sampling was found (Table 1). The bloom in this case was moderate. The state of the reservoir was similar in 2005 when microcystins were not detected [8]. However, three microcystins were identified in biomass in $2004(\mathrm{RR}+\mathrm{YR}+\mathrm{LR}) / \mathrm{LR}=4 / 1$ [11]. These concentrations show that in certain conditions this reservoir may be hazardous for recreational use.

In Lake Vaya microcystins were not detected in 2011. The same was the situation in 2005, but in 2004 microcystins $-\mathrm{RR},-\mathrm{YR}$ and $-\mathrm{LR}$ were detected there with ( $\mathrm{RR}+\mathrm{YR}+\mathrm{LR}) / \mathrm{LR}$ ratio in biomass 4/1 [8] [11]. The lack of microcystins is explainable by the species composition found in the lake at the time of sampling (Table 1) since the species found are well-known potential producers of other types of toxins (e.g.cylindrospermopsin). In any case, the high microcystin concentration in 2004 and the presence of potential cyanotoxin producers on the background of the strong algal blooms, observed since years in the lake [7] [16] [30] suggest the necessity of continuous monitoring of Vaya and prove its inclusion in the Red List of Bulgarian wetlands in Critically Endangered category [31] [32].

Microcystins were not detected in water of the reservoir Bistritsa nor in 2011, neither in 2005. However, the identification of extracellular microcystins in water sampled in $2004((\mathrm{RR}+\mathrm{YR}+\mathrm{LR}) / \mathrm{LR}=2 / 1)$ also suggests monitoring of the necessarily this reservoir for cyanotoxins [11]. Microcystins were not detected by HPLC in the biomass sample too but LC/MS confirmation showed trace of microcystins. Taking into account that the species found there was Microcystis wesenbergii which dominates the toxic Dourankoulak phytoplankton, we would like to provide a short discussion on its toxic potential. M. wesenbergii was enlisted in the earliest lists of toxic cyanoprokaryotes (e.g. [33]-[35]), and later one was included in the table of "confirmed toxin-producing species of cyanobacteria" ([36], p. 616). Some recent studies demonstrated by molecular and chemical methods that $M$. wesenbergii from Chinese waters did not produce microcystin [37]. This could be accepted at first glimpse as contradiction with our results and with the data cited above. However, it should be regarded just in a opposite way - as a support for previously expressed opinions that atoxigenic and toxigenic strains have been isolated not 
only from the same species from different sites but even from the same bloom (e.g. [36]). Toxicity not only varies between strains, but between clones of the same strain [36] and citations there]. Additionally, the influence of the environmental factors on toxin formation has been proved. For instance, a comparative study of 72 Finnish lakes [38] demonstrated that higher phosphorus concentrations favoured hepatotoxic Microcystis blooms (as it is generally the case of Dourankoulak [39]), whereas Anabaena blooms with unknown neurotoxicity were associated with low phosphorus and high nitrate concentrations.

The detected concentrations in Bulgarian water bodies are close to the quantities reported from Turkey [40]0.06 to $24.2 \mu \mathrm{g} / \mathrm{l}$, for Italy [41] -0.7 to $7.6 \mu \mathrm{g} / \mathrm{l}$ and for Poland [42]—-the highest total microcystin concentration $6.7 \mu \mathrm{g} / \mathrm{l}$ in 2002. Recent surveys from Bulgarian neighborhood countries Serbia [43], Macedonia [44], Greece [45] and Romania [46] also provide information on generally similar cyanobacterial blooms and clearly show the recognition of the problem as a new health risk factor [47]. The results obtained in our survey showed that MC-quantities are lower than amounts found in Czech Republic-up to $36 \mu \mathrm{g} / 1$ dissolved microcystins in water bodies [48], Slovakia-up to $1445.5 \mu \mathrm{g} / \mathrm{g}$ d.w. in biomasses [49] and in Finland [50] [51] — the highest total cell bound toxin concentration $42 \mu \mathrm{g} / \mathrm{l}$.

Nevertheless of the fact that the recorded MC concentrations were lower in comparison with some other European countries, the high percent of positive samples in which the most toxic microcystin-LR is recorded, can serve as a strong alarm for the necessity of a serious study and relevant discussion of the problem with responsible authorities at national level. Observations of water bodies at risk and monitoring actions for limitation and control of cyanobacterial toxic blooms are urgently needed, in combination with increased attention to the effects of cyanobacterial toxins on human health and health of aquatic ecosystems in Bulgaria.

\section{Acknowledgements}

Authors are thankful for the financial support of MESY scientific projects DDVU-02/77 and DFNI-T01/5 NANOSORBLAB. The authors would like to acknowledge the European Cooperation in Science and Technology, COST Action ES 1105 "CYANOCOST-Cyanobacterial blooms and toxins in water resources: Occurrence, impacts and management" for adding value to this study through networking and knowledge sharing with European experts and researchers in the field. The data cited in Stoyneva et al. 2013 [30] are property of the Executive Environmental Agency of the Ministry of Environment and Waters of Bulgaria.

\section{References}

[1] Chorus, I. and Bartram, J. (1999) Toxic Cyanobacteria in Water: A Guide to Public Health Significance, Monitoring and Management. E\&FN Spon, London. http://dx.doi.org/10.4324/9780203478073

[2] WHO (1998) Guidelines for Drinking-Water Quality, Health Criteria and other Supporting Information. 2nd Edition, Addendum to 2, World Health Organization, Geneva.

[3] Sivonen, K. and Jones, G.J. (1999) Cyanobacterial Toxins. In: Chorus, I. and Bartram, J., Eds., Toxic Cyanobacteria in Water: A Guide to Their Public Health Consequences, Monitoring and Management, E\&FN Spon, London, 41-91.

[4] Stoyneva, M.P. (1998) Development of the Phytoplankton of the Shallow Srebarna Lake (North-Eastern Bulgaria) Across the Trophic Gradient. In: Alvarez-Cobelas, M.C., Reynolds, S., Sanchez-Castillo, P. and Kristiansen, J., Eds., Phytoplankton and Trophic Gradients, Hydrobiologia, 369/370, 259-367.

[5] Stoyneva, M.P. (2000) Algological Studies of Bulgarian Coastal Wetlands. I. Species Composition of the Phytoplankton of Durankulak and Shabla-Ezeretz Lakes. Ann. Univ. Sof., 91, 27-48.

[6] Stoyneva, M.P. (2002) Algological Studies of Bulgarian Coastal Wetlands. II. Quantitative Structure of the Phytoplankton of Durankulak and Shabla-Ezeretz Lakes. Ann. Univ. Sof., 92, 91-109.

[7] Stoyneva, M.P. (2003) Steady-State Phytoplankton Assemblages in Shallow Bulgarian Wetlands. In: Naselli-Flores, L., Padisak, J. and Dokulil, M., Eds., Phytoplankton and Equilibrium Concept: The Ecology of Steady-State Assemblages. Kluwer Academic Publishers, 169-176.

[8] Pavlova, V., Stoyneva, M., Babica, P., Kohoutek, J. and Bratanova, Z. (2007) Microcystins Contamination and Cyanoprokaryote Bloomsin Some Coastal Bulgarian Wetlands. Conference Preprint Book, BULAQUA 2007, Second International Conference and Exhibition of Water Resources, Technologies and Services, Sofia, 221-226.

[9] Stoyneva, M.P. and Michev, T.M. (2007) State-of-Art Survey of Bulgarian Non-Lotic Wetlands and their Biodiversity. In: Michev, T.M. and Stoyneva, M.P., Eds., Inventory of Bulgarian Wetlands and their Biodiversity. Part 1: Non-Lotic Wetlands. Publ. House Elsi-M, Sofia, 88-108. 
[10] Stoyneva, M.P. and Temniskova-Topalova, D.N. (2007) Cyanoprokaryotes of Bulgarian Non-Lotic Wetlands and their Biodiversity. In: Michev, T.M. and Stoyneva, M.P., Eds., Inventory of Bulgarian Wetlands and their Biodiversity. Part 1: Non-Lotic Wetlands. Publ. House Elsi-M, Sofia, 155-167.

[11] Pavlova, V., Babica, P., Todorova, D., Bratanova, Z. and Maršálek, B. (2006) Contamination of Some Reservoirs and Lakes in Republic of Bulgaria by Microcystins. Acta Hydrochim Hydrobiol, 34, 437-441.

[12] Pavlova, V. (2007) Hygiene and Analytical Aspects of Microcystins Occurrence in Surface Water. Ph.D. Dissertation, National Center of Public Health Protection, Sofia.

[13] Teneva, I., Mladenov, R., Belkinova, D., Dimitrova-Dylgerova, I. and Dzhambazov, B. (2010) Phytoplankton Community of the Drinking Water Supply Reservoir Borovitsa (South Bulgaria) with an Emphasis on Cyanotoxins and Water Quality. Central European Journal of Biology, 5, 231-239.

[14] Teneva, I., Belkinova, D., Dimitrova-Dylgerova, I. and Mladenov, R. (2009) Phytoplankton Assemblages and Monitoring of Cyanotoxins in Trakiets Reservoir. Scientific Researches of the Union of Scientists in Bulgaria-Plovdiv, Series B, Natural Sciences and the Humanities, 12, Technics, Technologies, Natural Sciences and Humanities Session.

[15] Teneva, I., Belkinova, D., Dimitrova-Dylgerova, I., Vlaknova, M. and Mladenov, R (2010) Comparison and Toxic Potential of Cyanoprokaryota in Vacha Dam (Bulgaria). Second Balkan Conference on Biology, Plovdiv, 21-23 May 2010.

[16] Michev, T.M. and Stoyneva, M.P. (2007) Inventory of Bulgarian Wetlands and Their Biodiversity. Part 1: Non-Lotic Wetlands. Publishing House Elsi-M, Sofia, 364.

[17] Komárek, J. and Anagnostidis, K. (1999) Cyanoprokaryota. 1. Teil: Chroococcales. In: Ettl, H., Gärtner, G., Heynig, G. and Mollenhauer, D., Eds., Süßwasserflora von Mitteleuropa, Bd., Gustav Fischer, Jena.

[18] Komárek, J. and Anagnostidis, K. (2005) Cyanoprokaryota. 2. Teil: Oscillatoriales. In: Büdel, B., Gärtner, G., Krienitz, L. and Schagerl, M., Eds., Süßwasserflora von Mitteleuropa, Bd., Elsevier GmbH, München.

[19] Hindák, F. (2008) Colour Atlas of Cyanophytes. VEDA, Bratislava.

[20] Temniskova, D. and Stoyneva, M. (2011) Algology. General Part. Vol. 1. Pensoft, Sofia-Moscow, 1-512 [In Bulgarian].

[21] Temniskova, D. and Stoyneva, M. (2011) Algology. Systematic Part. Vol. 2. Pensoft, Sofia-Moscow, 513-1040 [In Bulgarian].

[22] Rott, E. (1981) Some Results from Phytoplankton Counting Intercalibration. Schweizerische Zeitschrift für Hydrologie, 43, 34-62.

[23] Deisinger, G. (1984) Leitfaden zur Bestimmung der planktischen Algen der Kärntner Seen und ihrer Biomasse Zusammengestellt von. Kärntner Institut fur Seenforschung.

[24] Poon, G.K., Griggs, L.J., Edwards, C., Beattie, K.A. and Codd, G.A. (1993) Liquid Chromatography-Electrospray Ionization-Mass Spectrometry of Cyanobacterial Toxins. Journal of Chromatography A, 628, 215-233. http://dx.doi.org/10.1016/0021-9673(93)80005-S

[25] Wu, Z., Shi, J., Xiao, P., Liu, Y. and Li, R. (2011) Phylogenetic Analysis of Two Cyanobacterial Genera Cylindrospermopsis and Raphidiopsis Based on Multi-Gene Sequences. Harmful Algae, 10, 419-425. http://dx.doi.org/10.1016/j.hal.2010.05.001

[26] Li, R., Carmichael, W.W., Brittain, S., Eaglesham, G.K., Shaw, G.R., Liu, Y. and Watanabe, M. (2001) First Report on the Cyanotoxins Cylindrospermopsin and Deoxycylindrospermopsin from Raphidiopsis curvata (Cyanobacteria). Journal of Phycology, 37, 1121-1126. http://dx.doi.org/10.1046/j.1529-8817.2001.01075.x

[27] Namikoshi, M., Murakami, T., Watanabe, M.F., Oda, T., Yamada, J., Tsujimura, S., Nagai, H. and Oishi, S. (2003) Simultaneous Production of Homoanatoxin-a, Anatoxin-a, and a New Non-Toxic 4-Hydroxyhomoanatoxin-a by the Cyanobacterium Raphidiopsis mediterranea Skuja. Toxicon, 42, 533-538.

[28] Stucken, K., John, U., Cembella, A., Murillo, A.A., Soto-Liebe, K., Fuentes-Valdes, J.J., Friedel, M., Plominsky, A.M., Vasquez, M. and Glöckneret, G. (2010) The Smallest Known Genomes of Multicellular and Toxic Cyanobacteria: Comparison, Minimal Gene Sets for Linked Traits and the Evolutionary Implications. PLoS ONE, 5, Article ID: e9235. http://www.plosone.org/article/info\%3Adoi\%2F10.1371\%2Fjournal.pone.0009235

[29] Jiang, Y., Xiao, P., Yu, G., Sano, T., Pan, Q. and Lia, R. (2012) Molecular Basis and Phylogenetic Implications of Deoxycylindrospermopsin Biosynthesis in the Cyanobacterium Raphidiopsis curvata. Applied and Environmental Microbiology, 78, 2256-2263.

[30] Stoyneva, M., Traykov, I., Uzunov, B., Tosheva, A. and Zidarova, R. (2013) Final Report of Ecotan EOOD on the Monitoring of Bulgarian Lakes on the Basis of the WFD Biological Element "Phytoplankton" for the Period 2011-2013 for the Executive Agency of Environment at the Ministry of Environment and Waters of Bulgaria.

[31] Michev, T.M. and Stoyneva, M.P. (2005) Red List of Bulgarian Wetlands: Conception, Creation and Application. An- 
nuaire de l’Université de Sofia “St KlimentOhridski”, Livre 4-10 ème Session Scientifigue, Sofia’03, Partie II, Tome 96, 71-76.

[32] Michev, T.M. and Stoyneva, M.P. (2007) Conservation of Bulgarian Non-lotic Wetlands. In: Michev, T.M. and Stoyneva, M.P., Eds, Inventory of Bulgarian Wetlands and Their Biodiversity, Part 1: Non-Lotic Wetlands, Publishing House Elsi-M, Sofia, 109-131.

[33] Kondratieva, N.V. (1968) Questions of Morphology and Systematics of Microcystisaeruginosa Kütz. emend. Elenk. and Its Close Species. In: Water Blooms, Vol. 1, 13-42 [In Russian].

[34] Kondratieva, N.V. and Kovalenko, O.N. (1975) Short Quide to the Species of Toxic Blue-Green Algae. Publishing House Naukova doumka, Kiiv, 80 [In Russian].

[35] Kirpenko, Y.A., Sirenko, L.A., Orlovskii, V.M. and Lukina L.F. (1977) Blue-Green Algal Toxins and the Animal Organism. Publishing House Naukovadoumka, Kiiv, 251 [In Russian].

[36] Dow, C.S. and Swoboda, U.K. (2000) Cyanotoxins. In: Whitton, B.A. and Potts, M., Eds., The Ecology of Cyanobacteria, Their Diversity in Time and Space, Kluwer Academic Publishers, Dordrecht, London, Boston, 613-632.

[37] Xu, Y., Wu, Z.X., Yu, B.S., Peng, X., Yu, G.L., Wei, Z.H., Wang, G.X. and Li, R.H. (2008) Non-Microcystin Producing Microcystis wesenbergii (Komárek) Komárek (Cyanobacteria) Representing a Main Waterbloom-Forming Species in Chinese Waters. Environmental Pollution, 156, 162-167. http://dx.doi.org/10.1016/j.envpol.2007.12.027

[38] Vaitomaa, J., Rapala, J., Seitsonen, J. and Sivonen, K. (1998) Factors Influencing Growth and Toxin Production of Cyanobacteria: Field, Mesocosm and Laboratory Experiments. In: Carmichael, W.W. and Paerl, H.W., Eds, Abstracts, 4th International Conference on Toxic Cyanobacteria, Beaufort, 51.

[39] Dimitrova, I. and Hainadjieva, V. (2006) Water Pollution in the Durankulak Lake, Bulgaria. In: Balwois 2006 Conference, 23-26 May 2006, Ohrid, Republic of Macedonia. http://www.balwois.com/balwois/administration/full_paper/ffp-694.pdf

[40] Albay, M., Matthiensen, A. and Codd, G. (2005) Occurrence of Toxic Blue-Green Algae in the Kucukcekmece Lagoon (Istanbul, Turkey). Environmental Toxicology, 20, 277-284.

[41] Funari, E., Gramaccioni, L. and Scardala, S. (2005) Cyanobacteria in Surface Water. In: Chorus, I., Ed., Current Approaches to Cyanotoxin Risk Assessment, Risk Management and Regulations in Different Countries, WaBoLu-Hefte, Federal Environmental Agency (Umweltbundesamt), Berlin, 81-83.

[42] Mankiewicz, J., Jurczak, T., Izydorczyk, K. and Zalewski, M. (2005) Regulation on Cyanotoxins in Legislation. In: Chorus, I., Ed., Current Approaches to Cyanotoxin Risk Assessment, Risk Management and Regulations in Different Countries, Wa BoLu-Hefte. Federal Environmental Agency (Umweltbundesamt), Berlin, 99-101.

[43] Pantelić, D., Svirčev, Z., Simeonović, J., Vidović, V. and Trajković, I. (2013) Cyanotoxins: Characteristics, Production and Degradation Routes in Drinking Water Treatment with Reference to the Situation in Serbia. Chemosphere, $\mathbf{1}$, 421-441.

[44] Blinkova, M., Zdraveski, N. and Krastić, S.S. (2012) Blue-Green Algae, the Janus of Nature. In: Proceedings of the 5th International Scientific Conference BALWOIS 2012, 28 May-2 June 2012, Ohrid.

[45] Cook, C.M., Moustaka-Gouni, M., Gkelis, S. and Lanaras, T. (2005) Cyanotoxin Risk Assessment, Risk Management and Regulation. In: Chorus, I., Ed., Current Approaches to Cyanotoxin Risk Assessment, Risk Management and Regulations in Different Countries, WaBoLu-Hefte, Federal Environmental Agency (Umweltbundesamt), Berlin, 69-75.

[46] Boaru, D.A., Dragoş, N., Welker, M., Bauer, A., Nicoară, A. and Schirmer, K. (2006) Toxic Potential of MicrocystinContaining Cyanobacterial Extracts from Three Romanian Freshwaters. Toxicon, 47, 925-932.

[47] Juković, M., Svirčev, Z., Baltić, V., Stojanović, D., Mihajlovic, A. and Baltić, M. (2008) Cyanotoxins-New Health Risk Factor in Serbia. Archive of Oncology, 16, 55-58.

[48] Bláhova, L., Babica, P., Adamovsky, O., Kohoutek, J., Maršalek, B. and Bláha, L. (2008) Analyses of Cyanobacterial Toxins (Microcystins, Cylindrospermopsin) in the Reservoirs of the Czech Republic and Evaluation of Health Risks. Environmental Chemistry Letters, 6, 223-227. http://dx.doi.org/10.1007/s10311-007-0126-x

[49] Maršálek, B., Bláha, L. and Hindák, F. (2000) Review of Toxicity of Cyanobacteria in Slovakia. Biologia, 55, 645-652.

[50] Spoof, L., Vesterkvist, P., Lindholm, T. and Meriluoto, J. (2003) Screening for Cyanobacerial Hepatotoxins, Microcyatins and Nodularin in Environmental Water Samples by Reversed-Phase Liquid Chromatography-Electrospray Ionization Mass Spectrometry. Journal of Chromatogaphy A, 1020, 105-119. http://dx.doi.org/10.1016/S0021-9673(03)00428-X

[51] WHO (2003) Guidelines for Safe Recreational Water Enviroments. Vol. 1. Coastal and Fresh Water. Chapter 8. Algae and Cyanobacteria in Fresh water. World Health Organization, Geneva, 151. 